\title{
EDITORIAL
}

\section{ANOS DE PÓS-GRADUAÇÃO SENSO ESTRITO}

A Escola de Enfermagem da Universidade de São Paulo, fundada em 1942 como Escola anexa à Faculdade de Medicina da USP, teve sua autonomia como Unidade da Universidade de Săo Paulo em 1963.

Em 1959 criou cursos de Pós-Graduação denominados Pedagogia e Didática Aplicada à Enfermagem, Administração de Serviços de Enfermagem e Administração de Ensino de Enfermagem. Estes cursos perduraram até os movimentos da Reforma Universitária na USP, em 1969 (Decreto n. 52.326, de 16 de dezembro de 1969), que instituiu formalmente os cursos de Pós-Graduação senso estrito, de níveis de Mestrado e Doutorado.

A implantação do Programa de Pós-Graduação em nível de Mestrado, em outubro de 1973, só foi possivel graças à ajuda financeira da Fundação Kellogg que, em 1959, já possibilitara a instalação do antigo curso de Pós-Graduação que, apesar de atender enfermeiros de serviço e docentes de escolas de enfermagem do Brasil, da América Latina e de paises de lingua portuguesa da África (Moçambique e Angola), não tinha como finalidade outorgar o título de Mestre. Este programa foi cursado por 491 alunos. Destes, 431 brasileiros e 60 estrangeiros.

Assim, em 1973, foi criado o Programa de Pós-Graduação, nível de Mestrado, na Escola de Enfermagem da USP que, com algumas modificaçð̄es, perdura até hoje.

Inicialmente criado para a área de concentração de "Fundamentos de Enfermagem", foi, posteriormente (1975), em virtude de ampliação e reformulação propostas à Câmara de Pós-Graduação da USP, aprovado para as áreas de concentração, quais sejam: Fundamentos de Enfermagem, Enfermagem Obstétrica e Neonatal, Enfermagem Pediátrica, Enfermagem Psiquiátrica e Administração de Serviços de Enfermagem.

Este programa de Pós-Graduação foi credenciado junto ao Conselho Federal de Educação pelo Parecer CFE n. $821 / 80$, de 11 de julho de 1980 , que alterou sua designação para Programa de Pós-Graduação em Eılfermagem, nível de Mestrado, com áreas de concentraçăo em Fundamentos de Enfermagem, Enfermagem Obstéirica e Neonatal, Enfermagem Psiquiátrica, Enfermagem Pediátrica e Administração de Serviços de Enfermagem. Em 1986 foi recredenciado junto ao Conselho Federal de Educação pelo Parecer CFE n. 429/86, de 2 de julho de 1986.

Durante estes 15 anos de funcionamento, em nivel de Mestrado, abriu inscrição nove vezes, num total de 410 inscriçoes, todas de enfermeiros, dos quais $\mathbf{3 4 2}$ foram selecionados e, destes, 233 se matricularam no Programa. Do total de alunos matriculados, 138 já concluiram o Programa.

O Programa de Pós-Graduação em Enfermagem, nivel de Doutorado, foi iniciado no Brasil, pioneiramente, em 1982, na USP, por esta Escola e pela Escola de Enfermagem de Ribeiråo Preto, como um Programa Interunidades. Credenciado junto ao Conselho Federal de Educação pelo Parecer CFE n. 363/86, de 5 de junho 
de 1986, desde sua instalação, já abriu inscrição 6 vezes, num total de 100 inscriçðes, todas de enfermeiros e, destes, 84 se matricularam. Dos matriculados, 35 já concluiram o Programa.

Em 1988, ao completar 15 anos, o Programa de Pós-Graduação em Enfermagem da Escola de Enfermagem da USP foi ampliado com a criaçào do nivel de Doutorado como extensão do Mestrado. Assim, atualmente, contamos com três Programas de Doutorado em Enfermagem: o de Enfermagem do Programa Interunidades já citado; o de Enfermagem Materno-Infantil do Departamento de Enfermagem da Escola Paulista de Medicina, criado em 1986; e, este da nossa Escola que, portanto, constitui-se no terceiro Programa deste nivel na América Latina.

São Paulo, dezembro de 1988.

\author{
Dra Maria Sumie Koizumi \\ Presidente \\ Comissão de Pós-Graduação
}

